АСОНОВ Николай Васильевич - доктор политических наук, профессор кафедры политологии Московского педагогического государственного университета (119991, Россия, г. Москва, ул. М. Пироговская, 1, стр. 1; nbassonov@yandex.ru)

МОИСЕЕВ Антон Борисович - старший преподаватель кафедры социологии и политологии Московского университета МВД России им. В.Я. Кикотя (117436, Россия, г. Москва, ул. Волгина, 12; borisyech71@mail.ru)

\title{
КТО ГЛАВНЫЙ ВИНОВНИК ВЕЛИКОЙ ОТЕЧЕСТВЕННОЙ ВОЙНЫ?
}

\begin{abstract}
Аннотация. В статье выдвигается альтернативная точка зрения относительно главного виновника Великой Отечественной войны, которым, согласно доводам автора, является либеральный лагерь, взявший на вооружение левоэкстремистскую идеологию радикализма, направленную на подавление культурно-исторических традиций «великих наций» Европы. Это вызвало в кругах западных патриотов ответную реакцию, поддержанную сталинским правительством СССР. Опасаясь дальнейшего сближения этих сил, грозившего либерализму поражением, он уступил национал-фашистам Европу и столкнул их с СССР, временно уйдя на второй план политической борьбы и рассчитывая, таким образом, на полное ослабление своих противников и последующее навязывание им своей воли.
\end{abstract}

Ключевые слова: Великая Отечественная война, левый и правый радикализм, левый и правый экстремизм, либерализм, национал-фашизм

Мир ли это? Ллойд Джорджк

B научной и учебной литературе продолжает бытовать мнение, согласно которому возникновение национал-фашизма стало ответной реакцией германского милитаризма, жаждущего реванша за поражение в Первой мировой войне и настроенного таким образом вывести свою страну из экономического кризиса. Его агрессивные планы разделили обойденные в своих амбициях малые страны Антанты, где самой обиженной была Италия [Фортунатов 2014: 332-333]. Думается, такой подход к данной проблеме требует пересмотра устоявшихся позиций и выявления главного виновника тех событий, сумевшего спровоцировать не только Великую Отечественную, но и Вторую мировую войну.

На что здесь стоит обратить внимание? В первую очередь нам надо исходить из того, что политическая наука признает наличие двух противоположных типов радикализма, добивающегося проведения коренных изменений действующей социально-политической системы. В зависимости от выбранного идеала радикализм подразделяется на правый и левый. Если правый радикализм ставит своей целью сохранение или реставрацию традиционной модели общества, то левые радикалы отвергают всякую традиционность и характерные для нее формы управления, религии и культуры, отражающие специфику этноцивилизационных особенностей человечества. Взамен предлагается новый тип объединения в глобальное сообщество, которого мир еще не знал. Именно к такому типу левого радикализма относится либерализм, стремящийся внушить нам мысль о строительстве «морального сообщества» и характерного для него второго типа культуры, «которая является глобальной, ...выходящей за рамки перспектив и идеалов какого-либо отдельного региона или одной страны» [Киссинджер 2015: 484].

В данной связи следует вспомнить, что в XX в. теория либерализма вслед за 
В. Гумбольдтом продолжала считать «ленивое государство» лучшим политическим устройством, существующим во имя индивида и выводящим за скобки его базовых интересов любовь к своей стране, своему народу и его культуре. Такая установка, по мысли Б. Муссолини, создавала «абсурдную договорную ложь политического равенства, наряженного в одеяние коллективной безответственности и рисующего миф о счастье», способном «свести человека до уровня животного, стремящегося только к одному - быть жирным и хорошо накормленным». Реализуя этот план, либерализм решил «распутать свои гордиевы узлы» «в кровопролитной мировой войне», которая стала продолжением его религии, отличающейся тем, что еще «никогда ни одна религия не требовала от своих сторонников таких жертв» [Муссолини 1997: 247].

Прямым следствием этой «мировой войны», ведущейся под лозунгом установления «братства и дружбы», выдвинутым В. Вильсоном, стала реализация либеральных планов по переустройству всей жизни мирового сообщества, благодаря чему entente cordiale (сердечное согласие) быстро уступило место rupture entente (сердечный разрыв). Важное место в этом проекте отводилось Лиге Наций - предшественнице ООН. Ее создание многими патриотами на Западе рассматривалось не как путь к предотвращению конфликтов, а как инструмент для их разжигания в интересах либеральной политической закулисы, стремящейся для начала ослабить Европу, навязав ей свой «великий интернационал».

Из-за этого Лигу Наций фашисты стали считать «детищем масонов», которое «преследует те же цели, что орган вольных каменщиков», т.е. «образование Соединенных Штатов Европы», а затем - «мировой федерации». В этой «федерации» не будет места ни национальной культуре, ни национальному типу власти. Как говорил Р. Куденхове-Калерги, являвшийся в то время одним из создателей Панъевропейского союза, мы создадим «тип человека грядущей эпохи ...тип бастарда; европейско-негроидальная раса соединит в себе многогранность расовых отличий человечества, благостное провидение даст нам и вождей этой новой Европы - в лице духовной аристократии благостной еврейской расы» [Иванов 1998: 477].

Такой путь модернизации Европы, строящийся в рамках Версальской системы, не устраивал тех, кто уважал свои национально-исторические корни. Как говорили идеологи фашизма, в эпоху, когда рушатся старые устои, гибнут старые ценности, разваливаются старые идеалы и религии, в этих условиях только одна идея способна сплотить массы - идея нации. И действительно, в противовес либерально-демократическим ценностям, построенным на культе личной наживы, лишающим рядовых граждан реальной защиты со стороны властных структур, фашизм брал под свое покровительство простого человека. Он выдвигал лозунг единства нации и сильного государства, с которым должен считаться мир, ставя национально-государственные интересы выше личных амбиций и требуя уважения к национальной истории и культуре.

Благодаря этой «политике защиты» вплоть до начала 40-х гг. XX в. фашизм сохранял к себе высокую степень доверия со стороны общества и даже рассматривался «как прогрессивное политическое движение». Многое из того, что предлагали в своих программах фашисты, оказалось близким и для русских эмигрантов, благодаря чему « $90 \%$ русской эмиграции если не прямо называли себя организациями фашистскими, то симпатизировали фашизму» [Назаров 1999: 603]. В рамках русского зарубежья с 1920-х гг. возник целый ряд политических объединений подобного толка. Среди них наибольшим авторитетом пользовались Организация российских фашистов, Всероссийская фашистская партия, Национальная организация российских фашистов и Монархо- 
фашистское движение. Даже президент «исполнительного комитета» сионистов Нахум Соколов, познакомившись с доктриной фашизма, прямо заявил: «Мы начинаем понимать истинную природу фашизма, настоящие евреи никогда не боролись против фашизма» [Окороков 2002: 18-19]. И это понятно. Ведь сионизм с момента политического оформления в 1897 г. сразу взял свои религиозно-культурные ценности под защиту от всякого чужеродного влияния, способного их «размыть» и дискредитировать их величие.

Борясь за сохранение национально-культурной идентичности «великих наций» Европы, фашизм выступал за тесный союз светской и духовной власти, о чем свидетельствуют Латеранские соглашения 1929 г. с папой римским. Следствием чего стало признание монархии в виде вождизма как положительной формы государственной власти. А его переход на позиции правого экстремизма стал следствием активной борьбы, развернутой им против левоэкстремистского радикализма либералов и коммунистов, захвативших с помощью насилия и закулисных политических интриг власть в передовых странах Европы и мечтающих о мировой гегемонии без национально-культурных особенностей.

Таким образом, дальнейшее решение этой проблемы на европейском уровне было немыслимо без участия Советского Союза, сумевшего создать мощный военно-технический потенциал и ставшего знаковым участником международной политики. Поражение троцкистов в нашей стране и реабилитация с 1934 г. патриотизма позволили взять под защиту и наши культурно-исторические ценности, отвергнутые левоэкстремистским лагерем большевиков, идущих с 1923 г. под лозунгом В. Александровского: «Старая Русь повешена, и мы ее палачи». Успех сталинской культурной политики вел к сближению СССР с теми, кто решил защищать свою цивилизационную самобытность, что грозило либерализму крупным поражением.

Единственный путь к успеху, который виделся ему в этом случае, на первом этапе сводился к стравливанию своих политических оппонентов в междоусобной борьбе. На втором этапе, когда они окажутся окончательно измотанными и разоренными войной, следовало утвердить над ними свою гегемонию, распространив ее в последующем на весь мир. Предшествующая аналогичная попытка, предпринятая по итогам Первой мировой войны, не привела либералов к решительной победе. Хотя в рамках Версальской системы ими были заложены институты глобального управления, начавшие формироваться вместе с Лигой Наций в 20-х гг. XX в. Еще в 1921 г. по инициативе «Круглого стола», созданного в 1891 г. и тесно связанного с рядом банкирских международных объединений типа Фонда Дитчли, был сформирован Совет по международным связям, а в 1925 г. - Фонд имени Фридриха Эберта, занятый внедрением глобалистских стандартов за счет подавления традиционных основ жизни в европейских странах.

Ради реализации этого проекта либеральная политическая закулиса дала возможность усилиться Германии и Италии путем уничтожения Локарнской системы, отказа с июля 1936 г. применять санкции против Гитлера и Муссолини, а также создания Комитета по невмешательству, что завершилось распадом Малой Антанты и образованием оси Берлин - Рим. К этому добавилось Мюнхенское соглашение 1938 г., за которым последовала «странная война» и сдача континентальной Европы. Тем самым были созданы условия для столкновения национал-фашистов с СССР. Идя на это, международный либерализм отводил себе роль второстепенного участника войны. Максимально экономя силы, он понимал, что военно-технический потенциал европейских государств, поставленный на службу политическим амбициям стран «оси», 
не позволит провести Blitzkrieg ни одной из сторон, вступивших в смертельную борьбу 22 июня 1941 г. Схватка между ними выльется в затяжную и максимально изматывающую форму противостояния. В итоге даже победившая сторона будет настолько измотана, что не сможет оказать успешное сопротивление либеральному лагерю.

И если на Западе Европы этот маневр удался вскоре после 1945 г., то для победы над советской моделью организации государства, власти и общества потребовалось долгих 46 лет, что позволило с 25 декабря 1991 г. перейти к строительству однополярного мира с характерным для него вторым типом культуры.

\title{
Список литературы
}

Иванов В.Ф. 1998. Русская интеллигенция и масонство: от Петра I до наших дней. М.: Изд-во журнала «Москва». 544 с.

Киссинджер Г. 2015. Мировой порядок. М.: АСТ. 512 с.

Муссолини Б. 1997. Доктрина фашизма. - Антология мировой политической мысли. В 5 т. М.: Мысль. Т. 2.

Назаров М.В. 1999. Тайна России. Историософия ХХ века. М.: Альманах «Русская идея» (Вып. 6). 736 с.

Окороков А.В. 2002. Фашизм и русская эмиграция (1920-1945). М.: Русаки. 593 с.

Фортунатов В.В. 2014. История: учебное пособие для бакалавров. СПб: Питер. 464 с.

ASONOV Nikolai Vasil'evich, Dr.Sci. (Pol.Sci.), Professor of the Chair of Political Science, Moscow State Pedagogical University (bld. 1, 1 Malaya Pirogovskaya St, Moscow, Russia, 119991; nbassonov@yandex.ru)

MOISEEV Anton Borisovich, Senior Lecturer of the Chair of Sociology and Political Science, V.Ya. Kikot' Moscow University of the Ministry of Internal Affairs of the Russian Federation (12 Akademika Volgina St, Moscow, Russia, 117437; borisyech71@mail.ru)

\section{WHO WAS TRULY RESPONSIBLE FOR THE GREAT PATRIOTIC WAR?}

\begin{abstract}
The article puts forward an alternative point of view on the chief perpetrator of the Great Patriotic War, which, according to the author's arguments, is the liberal camp, which has appreciated the left-extremist ideology of radicalism, aimed at suppressing the cultural and historical traditions of the great nations of Europe. This caused a toxic response in western patriotic circles, supported by the Stalinist government of the USSR. Fearing a further rapprochement of these forces, being threatened, liberalism and the liberal camp gave Europe to the national-fascists and pushed them to strike the USSR, temporarily leaving the political arena, and at the background of the political struggle, calculating the complete weakening of liberal forces opponents and the subsequent imposition of their will on both sides.

Keywords: Great Patriotic War, left-right radicalism, left-right extremism, liberalism, national-fascism
\end{abstract}

